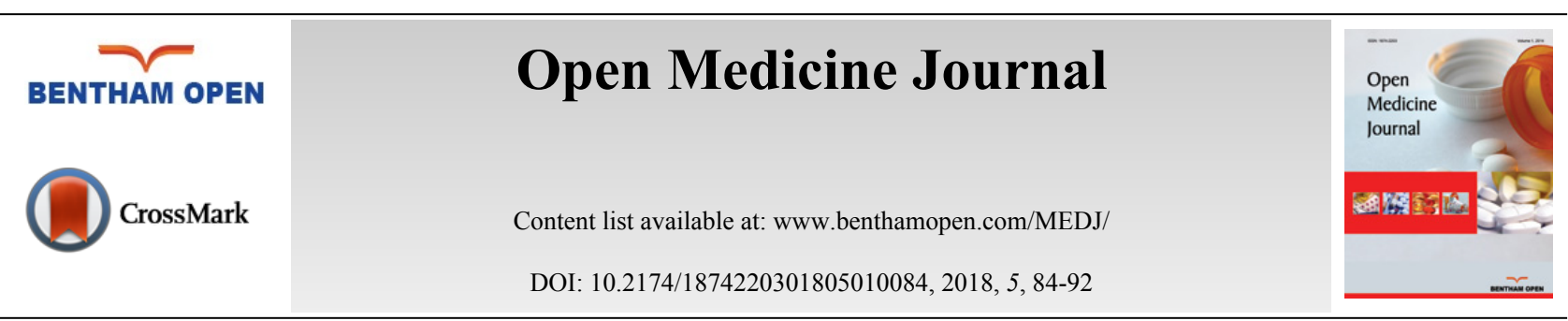

REVIEW ARTICLE

\title{
Areola Reconstruction: Principles and Techniques
}

\author{
Francesco Simonacci ${ }^{1, *}$, Nicolò Bertozzi ${ }^{1}$, Marianna Pesce ${ }^{2}$, Pier Luigi Santi ${ }^{2}$ and Edoardo Raposio ${ }^{1}$ \\ ${ }^{I}$ Department of Medicine and Surgery, Plastic Surgery Division, University of Parma, Parma, Italy \\ ${ }^{2}$ Department of Surgery and Related Methodologies, Plastic Surgery Section, University of Genova, Genova, Italy
}

Received: May 5, 2018

Revised: October 19, 2018

Accepted: October 23, 2018

\begin{abstract}
At the end of breast reconstruction, the creation of a natural-appearing areola is very important for patient satisfaction with the surgical result. The challenging aspects of achieving this include matching the color and texture as well as the size, shape, position, and projection of a normal areola, particularly in unilateral cases. The most common techniques that have been used to create a naturalistic nipple-areola complex have included skin grafting, tattooing, or a combination of both. Surgeons are finding that tattooing, the intradermal electric deposition of pigments, can be used to closely approximate natural areola pigmentation. Using the appropriate technique is essential as it is known that tattoo pigment fades over time and appears somewhat different after intradermal applied. Indeed, physicians' experience and color selection greatly affect the aesthetic outcome. Skin grafting has long been used in nipple-areola reconstruction, and skin donor sites such as retro- auricular, inner thigh, labia minora and contralateral areola have been employed. The choice of donor site depends on different factors, including the presence of a healthy contralateral areola and the skin tone of the patient. In some cases, tattooing may be used in conjunction with grafting. Regardless of areolar reconstructive technique, medical pigmentation is becoming a preferred method of producing a more realistic-appearing breast, although periodic touch-ups may be required for optimal results.
\end{abstract}

Keywords: Areola reconstruction, Breast reconstruction, Areola tattooing, Areola grafting, Aesthetic surgery, Reconstructive surgery.

\section{INTRODUCTION}

Patients with areola loss because of trauma, breast cancer removal, or congenital malformation can experience psychological distress even once breast reconstruction has been performed. Areola reconstruction can also be performed following congenital or delayed disease, burn-related deformities, and alterations post breast surgeries [1]. Furthermore, significant psychosocial benefits are proved for women undergoing whole breast reconstruction after breast cancer resection. Many surgical techniques and devices have been used for breast reconstruction to restore an aesthetically pleasing breast profile, such as local flaps, implants, expanders, autologous fat grafting and adipose-derived stem cells [2 - 32]. Studies have shown that areola re-creation improves also patient's gratification and satisfaction of body image [33].

Hence, breast reconstruction can be concluded only by areola recreation, matching the size, shape, projection, and position of contralateral nipple. Areolar reconstruction can be considered as the last reconstructive step in breast reconstruction [34 - 36], as a reconstructed breast without an areola remains anatomically incomplete. One of the main issues in areola reconstruction includes recreating pigmentation and texture matching the native one. Grafting or paramedical pigmentation or a combination of both are the commonly employed strategies. Timing for reconstruction also matters. Usually at the time of breast reconstruction or in delayed surgical session, skin grafting is performed, otherwise tattooing occurs about 2 months after nipple creation, however, several authors reported satisficing results with simultaneous nipple reconstruction and paramedical pigmentation [37].

\footnotetext{
* Address correspondence to this author at the Department of Medicine and Surgery, Plastic Surgery Division, Cutaneous, Regenerative, Mininvasive and Plastic Surgery Unit, Parma University and Maggiore Hospital, Via Gramsci 14, 43126 Parma, Italy; Tel: 39/3293350521; E-mail: francescosimonacci@hotmail.it
} 
Areola reconstruction is often performed by grafting from the upper inner thigh or contralateral areola or alternatively by intradermal paramedical pigmentation [38]. In order to provide a color and produce a more realistic appearance,several authors reported that tattooing is the ideal technique among the areola reconstruction procedures [39 - 41]. Skin grafting remains an important technique worldwide; tattooing is considered an effective technique for areola reconstruction, however, experience, periodic maintenance and special medical equipment are required for optimal results. Nevertheless, Kargül et al. reported that grafting from the contralateral areola allowed obtaining the best color match compared to medical pigmentation or the use of skin graft from groin [42].

\section{TATTOOING}

The use of areola tattooing is a major adjunct to reconstruction. An excellent areolar color matching with limited morbidity could be provided by tattooing itself or in conjunction with skin grafting. After surgery, trauma, or illness, it is possible to use paramedical pigmentation (tattoo or permanent makeup techniques) which allows returning the areola to the previous original color toning.

Size, color, and nipple-areola location without needing donor tissue can be adjusted freely by paramedical pigmentation; this is the greatest advantages of tattooing technique. In 1975, Rees [43] and Spear et al. [44] introduced the tattooing uses of intradermal pigments, chosen from a color plate that typically included an iron and titanium oxide mixture. Although, as reported, revision surgery was often necessary due to the presence of pigments in postsurgical breast scars or other body areas. The most difficult goal and the crucial part of areola tattooing is the color selection [45]. Factors contributing to the difficulty of more suitable color selection are; fading of the pigment and the disparity between the color chosen and their appearance after intradermal application. Many publications reported the color disappearing after intradermal application; authors suggested adopting a darker color tone than required as a countermeasure to fading [46, 47].

In case of unilateral areola reconstruction, the color should be selected slightly darker compared to the contralateral areola [1]. There are no publications addressing the meaning of the term 'darker', whether it is more adequate to choose a dark color with a lower tone or a more highly saturated, rich, vivid color is yet unclear.

The disparity between the chosen color and the color appearance once it has introduced into the skin is another factor contributing to difficulties in pigment selection. As reported in literature, the tonality of the skin patient, the inflammation and the scarring tissue influence the appearance of selected color once it has introduced into the skin after tattooing. In order to assist a better color selection for nipple-areola complex reconstruction by tattooing, Tomita et al. [48] studied the post tattooing color variation over time. They reported that after paramedical pigmentation, the pigment spreads directly from superficial layers of the skin to the deeper ones. Following about a week as scarring occurs causing the loss of some keratin pigment, and, after 2-3 months, the more intense skin turnover of superficial layers compared to the deeper ones determines the loss of further pigment [49, 50]. In addition, the phagocytosis by macrophages and lymphatic drainage decreases the pigment concentration $[51,36]$; this is particularly significant in case when pigment is deposited into the deeper dermis layer. The bulky scar formation as a result of undesired skin damage and the needless blood loss cause the pigment excretion that may contribute to premature color fading as well $[39,41]$. Because of these reasons, maintaining an appropriate depth, minimizing skin damage, and tattooing carefully are important to obtain a good result. The pigment placement too deeper leads to macrophage processing and removal; while too superficial may cause the pigment extrusion due to the skin desquamation, both resulting in early color fading [52]. According to Tomita et al. [48], it is important to balance the proportion of pigments structural elements into the final mixture to create the desired color and avoid the color changes after areola tattooing. In fact, as they reported, the ideal paramedical color fundamental properties for areola tattooing must include the tone bit less bright, less tending to red, and containing more yellowness when compared with the native side [48]. To avoid bacterial or viral infections, disease sterile technique is mandatory. Spear et al. [36] reported that $9.5 \%$ of areolas needed makeover due to pigment fading, and that $60 \%$ of all areolas were characterized as too bright during the follow-up. For this reason, over the time to obtain an aesthetically pleasing color match, many patients will likely require touch-up tattooing. Usually, the tattooing area undergoes desquamation and scab formation for 3-5 days [36] and should be treated with antibiotic topic crème, and the dressing should be replaced daily [36]. Subsequently, slight fading of color may occur, and several patients desire a touch-up after few months [36]. Areola tattooing marks the end of a breast reconstruction plan [53].

Halvorson et al. [54] reported the use of three-dimensional technique for areola tattooing. It is essentially the inverse of traditional nipple-areola complex tattoo technique. Most nipple-areola complex tattoos are performed using lighter ink for the areola and a central circle of darker ink for the nipple; instead, the three-dimensional technique serves the 
creation of a lighter inner circle with a dark border, which is thickened inferiorly to create a shadow effect. Although this procedure can be performed with standard medical tattooing equipment, a professional tattoo artist can assist the surgeon with specialized equipment and ink in order to produce an outstanding result, including tattooing of Montgomery glands. When nipple projection is almost or completely lost, this technique can give the illusion of projection without surgical revision and by adjusting the darker ring of color around the nipple, it is possible to contrast asymmetries without surgery.

Usually, the first areola paramedical pigmentations may appear with unequal marking or irregular profile that are difficult to correct regardless of any technical learning curve. The tattooing procedure of areola should be performed with care to obtain a uniform color and regular contour [55] (Figs. 1-5).

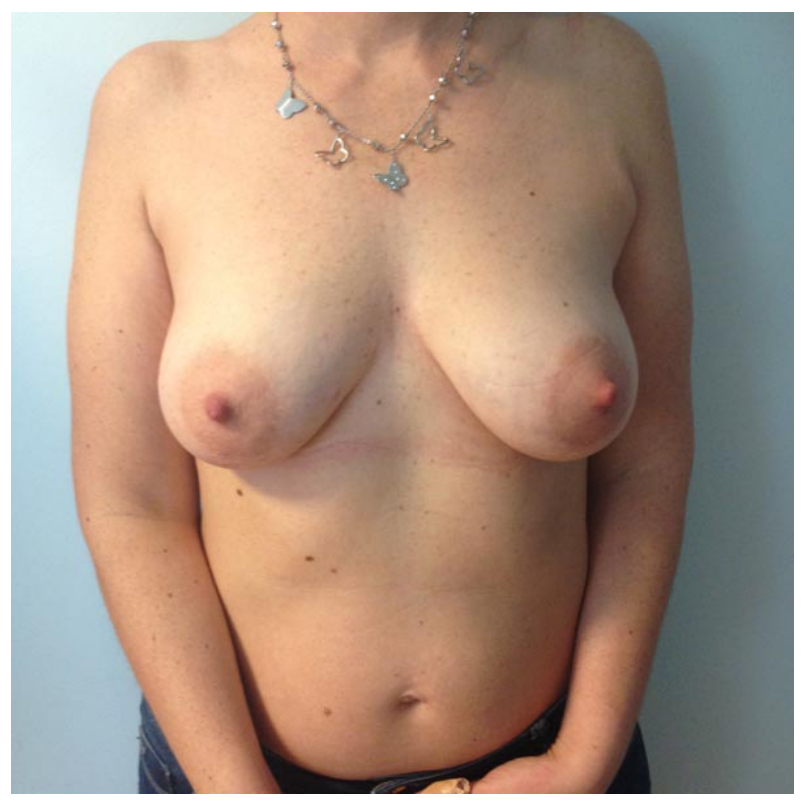

Fig. (1). A 38-year-old female patient who had breast cancer involving the right nipple-areola complex.

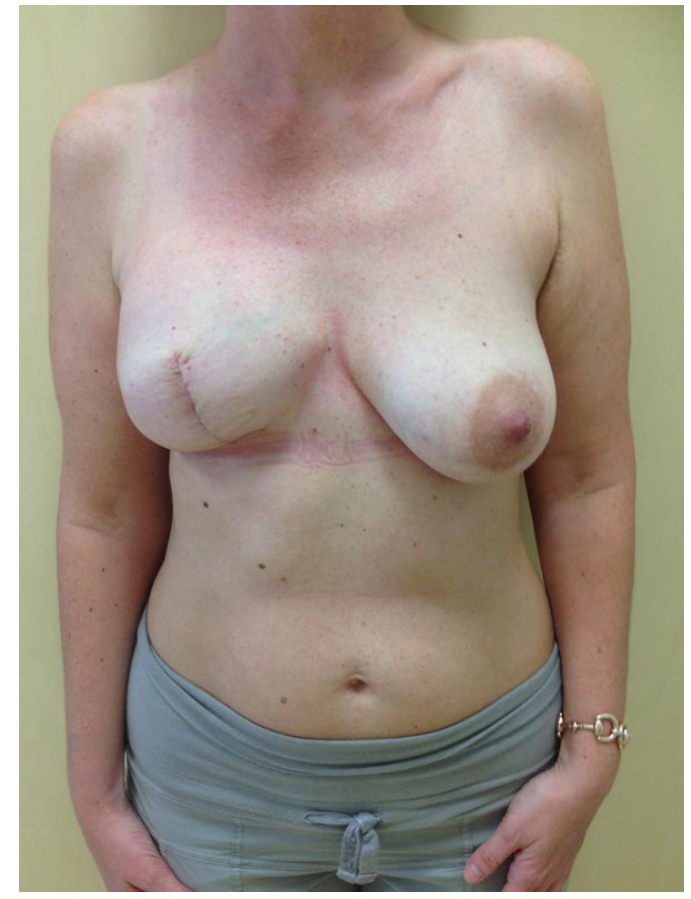

Fig. (2). Follow-up two weeks after inferior-central quadrantectomy. 


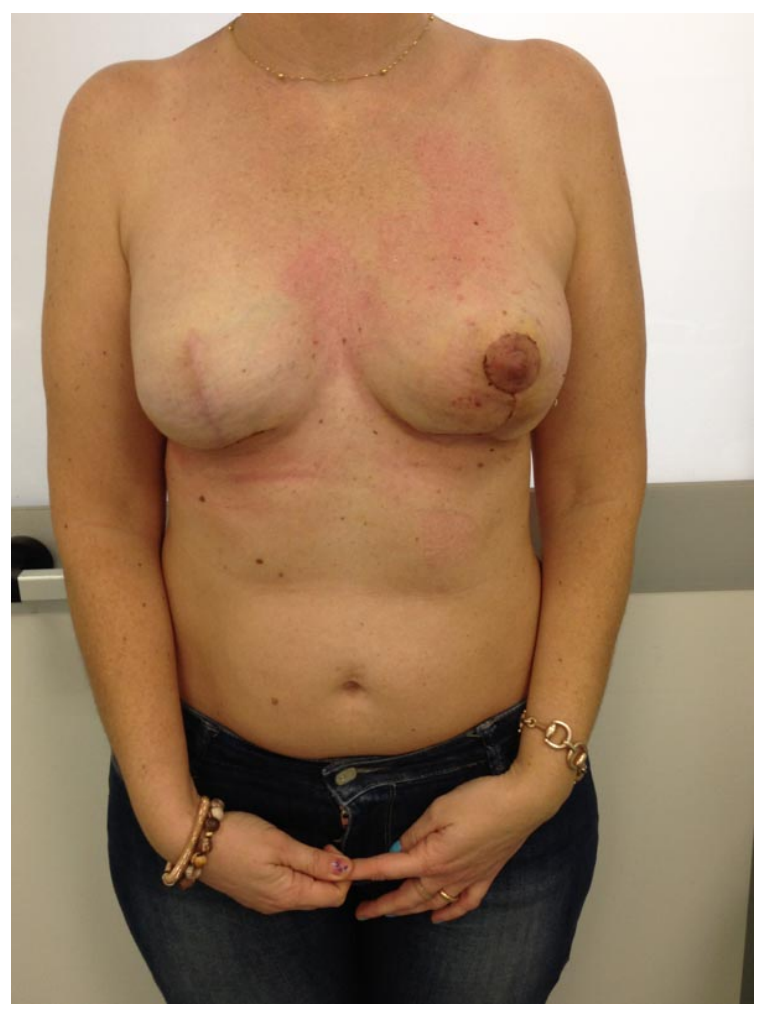

Fig. (3). Follow-up two months after symmetrization of the left breast.

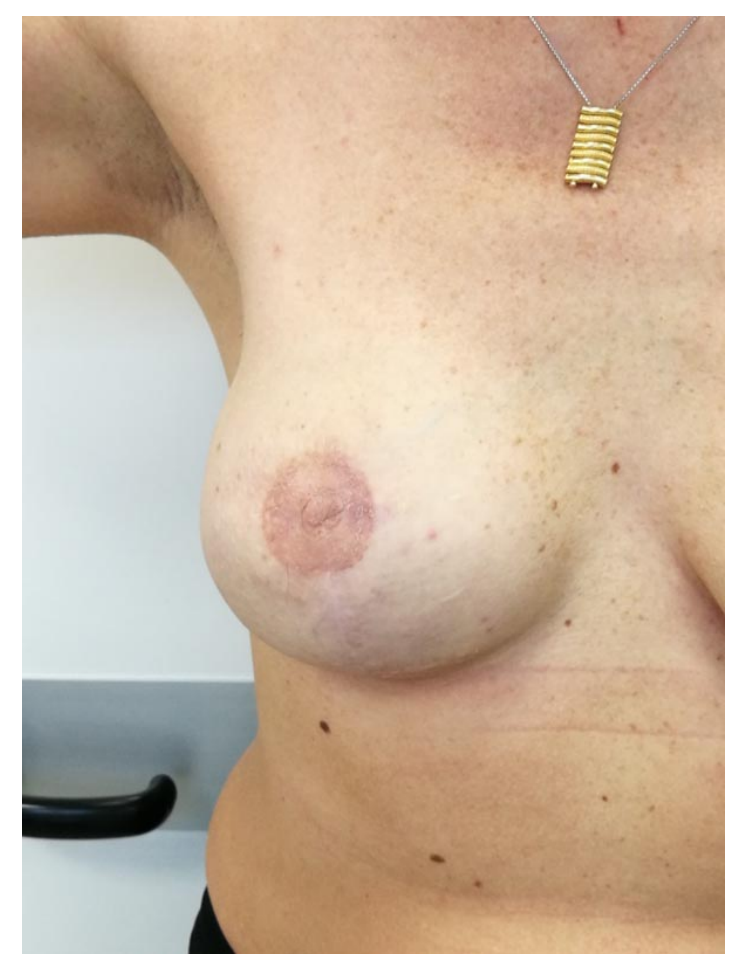

Fig. (4). Nipple-areola complex tattooed 3 months after the second surgery; frontal view. 


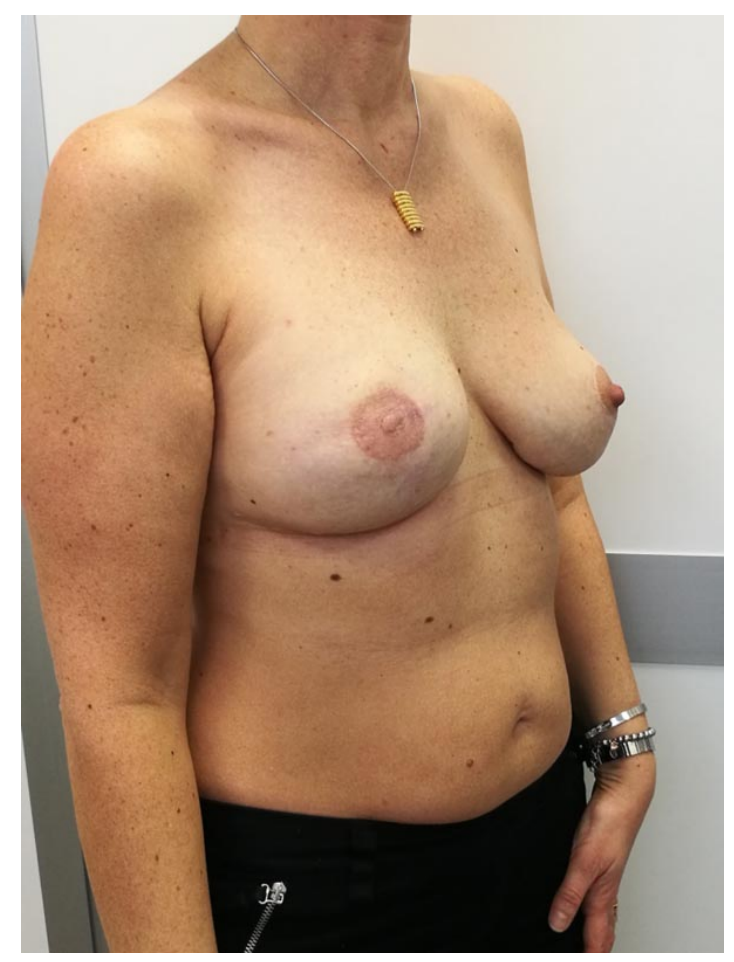

Fig. (5). Nipple-areola complex tattooed 3 months after second surgery; lateral view.

\section{GRAFTING}

The use of split and full thickness skin grafts from different donor sites, as the contralateral normal areola, retroauricular skin, labia minora and inner thigh was the main technique prior to the use of paramedical pigmentation for reconstruction of areola by tattooing. Often donor sites other than the native areola are declined from patients, because pain, graft survival, and the color match achieved are often unsuitable or inconstant. Textured, wrinkled surface and distinctive pigmentation of a normal areola with Montgomery tubercles are advantages of areola skin grafting compared to tattooing [56]. Adams [57] reported the use of free labia minora graft to supply pigmented skin, in case of donor site, the contralateral breast is unavailable. However, several patients desire to preserve the donor site, because labial skin is more dark, making the reconstructed areola excessively pigmented. A donor site a little less pigmented than areola is necessary for an acceptable color match when the difference between the tonality of areola and that of the surrounding breast skin is not relevant in several white patients. Edwards et al. [58] studied the color difference of human skin phototype by spectrophotometry. Patients readily accepted the skin of the upper and inner thigh as donor site because it is darker than breast skin and less pigmented than labial skin [59]. As concern unilateral cases, split and full-thickness skin grafts match the opposite normal areola with good results; they are dark enough and have proven satisfactory [59]. Any areolar pigmented scar, or remaining nipple, is brought through a small opening in the center of skin graft after its placement on a prepared deep dermal bed [59]. If there is no suitable tissue to simulate the papilla, the tip of the opposite normal nipple may be transplanted [59]. Schwartz et al. [60] described areola reconstruction as a full-thickness skin graft from the normal areola. The operation consists of preparing a deep dermal bed for transplanting the outer ring of contralateral areola as a long strip of full-thickness skin graft. The central end of spiral full-thickness skin graft assembled to simulate the nipple prominence. By a fine suture and a tie-over pressure dressing, it is possible to keep it stationary on the site. The procedure is most acceptable for wide areolas, and for excellent result, the final dimension of each areola should be the same [60]. In order to treat darker complexion cases, the inguinal-perineal skin has been proposed [61]. However, these donor sites are not often valued by patients despite the scar could be camouflaged and simply covered by clothes [61]. Brent et al. [62] reported the use of a full-thickness graft from the retro-auricular donor site, because it allows to obtain a typically pinkish color, most acceptable for patients of fair complexion, such as true blondes and red-haired woman.

\section{DISCUSSION}

The ideal areola reconstruction should be symmetrical with the normal breast and provides a good color and texture 
match. Over the last decades to achieve these objectives, many techniques have been developed. The use of fullthickness skin grafts from different areas of the body, as well as the contralateral areola, the upper, inner side of the thigh or labia minora allowed reconstructing the areola [63, 64]. However, the original pigmentation of skin grafts is usually transitory and changes over time. Furthermore, anesthetic scar at the level of donor site, deformity and asymmetry of the areola are common complications after incomplete graft. When depigmentation or graft failure occurs, delayed paramedical pigmentation of the areola has been performed to correct them [44]. Tattooing of areola as first reconstruction option is an efficient and secure method that can be used to achieve good symmetry and color match. After areola paramedical tattooing, no donor sites are needed and major complications are not observed, even if strict sterility procedures are not followed, the infection may occur [44]. Areola tattooing inevitably requires a more or less rapid learning curve, the pigment should be manually mixed to find the normal areola color match, and the color shade occasionally changes once pigment is introduced into the dermis. This undesired effect appears in an evident color mismatch, or, in an early color fading when the pigment is not introduced deep enough. Over the time, the pigment color fading is a not rare event reported in the literature. For this reason, for areola tattooing, the selection of a darker color shade compared to the normal one is relevant, in order to contrast the potential pigment fading over the time, resulting in a more appropriate match [44]. The introduction of three-dimensional tattooing technique was a significant advance in obtaining improved aesthetic results for women undergoing breast reconstruction, in fact, any prominence will achieve three-dimensionality when light and shadow are used appropriately in two dimensions [54].

Shade discrepancies can be easily adjusted by further areola tattooing, however, a quick improvement of overall results was reported after an adequate learning curve.

\section{CONCLUSION}

In the last decade, authors tried to control and predict skin grafts pigmentation for areola reconstruction. Despite various attempts, clinical experience proves that this is difficult to achieve. A problem with all skin grafts is the morbidity of donor site, sometimes refused form patients. Therefore, in most cases, immediate areola tattooing has made skin grafting dispensable.

\section{CONSENT FOR PUBLICATION}

Not applicable.

\section{CONFLICT OF INTEREST}

The authors declare that there is no conflict of interest, financial or otherwise.

\section{ACKNOWLEDGEMENTS}

Declared none.

\section{REFERENCES}

[1] Nimboriboonporn A, Chuthapisith S. Nipple-areola complex reconstruction. Gland Surg 2014; 3(1): 35-42. [PMID: 25083492]

[2] Raposio E, Santi PL. Topical application of DMSO as an adjunct to tissue expansion for breast reconstruction. Br J Plast Surg 1999; 52(3): 194-7.

[http://dx.doi.org/10.1054/bjps.1998.3096] [PMID: 10474470]

[3] Galli A, Raposio E, Santi P. Reconstruction of full-thickness defects of the thoracic wall by myocutaneous flap transfer: Latissimus dorsi compared with transverse rectus abdominis. Scand J Plast Reconstr Surg Hand Surg 1995; 29(1): 39-43. [http://dx.doi.org/10.3109/02844319509048421] [PMID: 7597388]

[4] Raposio E, Belgrano V, Santi P, Chiorri C. Which is the ideal breast size?: Some social clues for plastic surgeons. Ann Plast Surg 2016; 76(3): 340-5.

[http://dx.doi.org/10.1097/SAP.0000000000000471] [PMID: 25664414]

[5] Raposio E, Cicchetti S, Adami M, Ciliberti RG, Santi PL. Computer planning for breast reconstruction by tissue expansion: An update. Plast Reconstr Surg 2004; 113(7): 2095-7.

[http://dx.doi.org/10.1097/01.PRS.0000121189.51406.12] [PMID: 15253203]

[6] Raposio E, Caregnato P, Barabino P, et al. Computer-based preoperative planning for breast reconstruction in the woman with unilateral breast hypoplasia. Minerva Chir 2002; 57(5): 711-4.

[PMID: 12370677] 
[7] Fan J, Raposio E, Wang J, Nordström RE. Development of the inframammary fold and ptosis in breast reconstruction with textured tissue expanders. Aesthetic Plast Surg 2002; 26(3): 219-22. [http://dx.doi.org/10.1007/s00266-002-1477-0] [PMID: 12140704]

[8] Porro I, Schenone A, Fato M, Raposio E, Molinari E, Beltrame F. An integrated environment for plastic surgery support: Building virtual patients, simulating interventions, and supporting intraoperative decisions. Comput Med Imaging Graph 2005; 29(5): 385-94. [http://dx.doi.org/10.1016/j.compmedimag.2005.02.005] [PMID: 15893913]

[9] Simonacci F, Bertozzi N, Grieco MP, Grignaffini E, Raposio E. Autologous fat transplantation for breast reconstruction: A literature review. Ann Med Surg (Lond) 2016; 12: 94-100.

[http://dx.doi.org/10.1016/j.amsu.2016.11.012] [PMID: 27942383]

[10] Raposio E, Caruana G, Petrella M, Bonomini S, Grieco MP. A standardized method of isolating adipose-derived stem cells for clinical applications. Ann Plast Surg 2016; 76(1): 124-6. [http://dx.doi.org/10.1097/SAP.0000000000000609] [PMID: 26418805]

[11] Raposio E, Caruana G, Bonomini S, Libondi G. A novel and effective strategy for the isolation of adipose-derived stem cells: minimally manipulated adipose-derived stem cells for more rapid and safe stem cell therapy. Plast Reconstr Surg 2014; 133(6): 1406-9. [PMID: 24867723]

[12] Scanarotti C, Bassi AM, Catalano M, et al. Neurogenic-committed human pre-adipocytes express CYP1A isoforms. Chem Biol Interact 2010; 184(3): 474-83.

[http://dx.doi.org/10.1016/j.cbi.2010.01.009] [PMID: 20080079]

[13] Raposio E, Guida C, Baldelli I, et al. Characterization and induction of human pre-adipocytes. Toxicol 2007; 21(2): 330-4. in vitro [http://dx.doi.org/10.1016/j.tiv.2006.09.022] [PMID: 17113745]

[14] Coradeghini R, Guida C, Scanarotti C, et al. A comparative study of proliferation and hepatic differentiation of human adipose-derived stem cells. Cells Tissues Organs (Print) 2010; 191(6): 466-77. [http://dx.doi.org/10.1159/000273266] [PMID: 20051678]

[15] Aluigi MG, Coradeghini R, Guida C, et al. Pre-adipocytes commitment to neurogenesis 1: Preliminary localisation of cholinergic molecules. Cell Biol Int 2009; 33(5): 594-601. [http://dx.doi.org/10.1016/j.cellbi.2009.02.014] [PMID: 19286468]

[16] Raposio E, Guida C, Coradeghini R, et al. In vitro polydeoxyribonucleotide effects on human pre-adipocytes. Cell Prolif 2008; 41(5): 739-54. [http://dx.doi.org/10.1111/j.1365-2184.2008.00547.x] [PMID: 18673371]

[17] Caruana G, Bertozzi N, Boschi E, Pio Grieco M, Grignaffini E, Raposio E. Role of adipose-derived stem cells in chronic cutaneous wound healing. Ann Ital Chir 2015; 86(1): 1-4. [PMID: 25818696]

[18] Raposio E, Bonomini S, Calderazzi F. Isolation of autologous adipose tissue-derived mesenchymal stem cells for bone repair. Orthop Traumatol Surg Res 2016; 102(7): 909-12. [http://dx.doi.org/10.1016/j.otsr.2016.07.006] [PMID: 27638160]

[19] Raposio E, Bertozzi N, Bonomini S, et al. Adipose-derived stem cells added to platelet-rich plasma for chronic skin ulcer therapy. Wounds 2016; 28(4): 126-31. [PMID: 27071140]

[20] Raposio E, Calderazzi F. Fat grafting for chronic heel pain following surgery for adult flatfoot deformity: Pilot study. Foot 2017; 31 : 56-60 [http://dx.doi.org/10.1016/j.foot.2017.02.005] [PMID: 28549282]

[21] Raposio E, Bertozzi N. Isolation of ready-to-use Adipose-derived Stem Cell (ASC) pellet for clinical applications and a comparative overview of alternate methods for ASC isolation. Curr Protoc Stem Cell Biol 2017; 41

[22] Simonacci F, Bertozzi N, Grieco MP, Grignaffini E, Raposio E. Procedure, applications, and outcomes of autologous fat grafting. Ann Med Surg (Lond) 2017; 20: 49-60. [http://dx.doi.org/10.1016/j.amsu.2017.06.059] [PMID: 28702187]

[23] Bertozzi N, Simonacci F, Grieco MP, Grignaffini E, Raposio E. The biological and clinical basis for the use of adipose-derived stem cells in the field of wound healing. Ann Med Surg (Lond) 2017; 20: 41-8. [http://dx.doi.org/10.1016/j.amsu.2017.06.058] [PMID: 28702186]

[24] Raposio E, Simonacci F, Perrotta RE. Adipose-derived stem cells: Comparison between two methods of isolation for clinical applications. Ann Med Surg (Lond) 2017; 20: 87-91. [http://dx.doi.org/10.1016/j.amsu.2017.07.018] [PMID: 28736612]

[25] Simonacci F, Bertozzi N, Raposio E. Off-label use of adipose-derived stem cells. Ann Med Surg (Lond) 2017; $24: 44-51$. [http://dx.doi.org/10.1016/j.amsu.2017.10.023] [PMID: 29123656]

[26] Simonacci F, Grieco MP, Bertozzi N, Raposio E. Autologous fat transplantation for secondary breast reconstruction: Our experience. G Chir 2017; 38(3): 117-23. [http://dx.doi.org/10.11138/gchir/2017.38.3.117] [PMID: 29205140]

[27] Raposio E, Bellini E, Bertozzi N, Simonacci F, Grieco M. Autologous fat transfer in reconstructive breast surgery: Surgical technique. Gazz Med Ital 2018; 177: 97-103. 
[28] Simonacci F, Bertozzi N, Grieco MP, Raposio E. The art and science beyond body contouring a solution for massive weight loss patients. Prensa Med Argent 2018; 104: 2. [http://dx.doi.org/10.4172/0032-745X.1000282]

[29] Gardani M, Bertozzi N, Grieco MP, et al. Breast reconstruction with anatomical implants: A review of indications and techniques based on current literature. Ann Med Surg (Lond) 2017; 21: 96-104. [http://dx.doi.org/10.1016/j.amsu.2017.07.047] [PMID: 28794874]

[30] Polotto S, Grieco MP, Simonacci F, et al. Reduction mammoplasty techniques in post-bariatric patients: Our experience. Acta Biomed 2017; 88(2): 156-60.

[PMID: 28845829]

[31] Grieco MP, Simonacci F, Bertozzi N, Grignaffini E, Raposio E. Breast reduction: A case series analysis. Eur Mediterranean Biomed J 2016; 11: 157-64.

[32] Grieco M, Grignaffini E, Simonacci F, Di Mascio D, Raposio E. Post-bariatric body contouring: Oue experience. Acta Biomed 2016; 87(1): 70-5.

[PMID: 27163898]

[33] Evans KK, Rasko Y, Lenert J, Olding M. The use of calcium hydroxylapatite for nipple projection after failed nipple-areolar reconstruction: Early results. Ann Plast Surg 2005; 55(1): 25-9. [http://dx.doi.org/10.1097/01.sap.0000168370.81333.97] [PMID: 15985787]

[34] Turgut G, Sacak B, Görgülü T, Yesilada AK, Bas L. Nipple reconstruction with bipedicled dermal flap: A new and easy technique. Aesthetic Plast Surg 2009; 33(5): 770-3.

[http://dx.doi.org/10.1007/s00266-009-9368-2] [PMID: 19495857]

[35] Levites HA, Fourman MS, Phillips BT, et al. Modeling fade patterns of nipple areola complex tattoos following breast reconstruction. Ann Plast Surg 2014; 73(Suppl. 2): S153-6. [http://dx.doi.org/10.1097/SAP.0000000000000120] [PMID: 24727445]

[36] Spear SL, Arias J. Long-term experience with nipple-areola tattooing. Ann Plast Surg 1995; 35(3): 232-6. [http://dx.doi.org/10.1097/00000637-199509000-00002] [PMID: 7503514]

[37] Vandeweyer E. Simultaneous nipple and areola reconstruction: A review of 50 cases. Acta Chir Belg 2003; 103(6): 593-5. [http://dx.doi.org/10.1080/00015458.2003.11679498] [PMID: 14743565]

[38] Nagura-Inomata N, Iwahira Y, Hayashi N, Komiya T, Takahashi O. The optimal reconstruction size of nipple-areola complex following breast implant in breast cancer patients. Springerplus 2016; 5: 579. [http://dx.doi.org/10.1186/s40064-016-2230-5] [PMID: 27247876]

[39] Bhatty MA, Berry RB. Nipple-areola reconstruction by tattooing and nipple sharing. Br J Plast Surg 1997; 50(5): 331-4. [http://dx.doi.org/10.1016/S0007-1226(97)90541-5] [PMID: 9245866]

[40] Henseler H, Cheong V, Weiler-Mithoff EM, MacKay IR, Webster MH. The use of Munsell colour charts in nipple-areola tattooing. Br J Plast Surg 2001; 54(4): 338-40. [http://dx.doi.org/10.1054/bjps.2001.3581] [PMID: 11355995]

[41] El-Ali K, Dalal M, Kat CC. Tattooing of the nipple-areola complex: Review of outcome in 40 patients. J Plast Reconstr Aesthet Surg 2006; 59(10): 1052-7.

[http://dx.doi.org/10.1016/j.bjps.2006.01.036] [PMID: 16996427]

[42] Kargül G, Deutinger M. Reconstruction of the breast areola complex. Comparison of different techniques. Handchir Mikrochir Plast Chir 2001; 33(2): 133-7. [PMID: 11329892]

[43] Rees TD. Reconstruction of the breast areola by intradermal tattooing and transfer. Case report. Plast Reconstr Surg 1975; 55(5): 620-1. [http://dx.doi.org/10.1097/00006534-197505000-00019] [PMID: 1144541]

[44] Spear SL, Convit R, Little JW III. Intradermal tattoo as an adjunct to nipple-areola reconstruction. Plast Reconstr Surg 1989; 83(5): 907-11. [http://dx.doi.org/10.1097/00006534-198905000-00027] [PMID: 2710843]

[45] Little JW, Spear SL. The finishing touches in nipple areola reconstruction. Perspect Plast Surg 1998; 2: 1-22.

[46] Becker H. The use of intradermal tattoo to enhance the final result of nipple-areola reconstruction. Plast Reconstr Surg 1986; 77(4): 673-6. [http://dx.doi.org/10.1097/00006534-198604000-00032] [PMID: 3952225]

[47] Levites HA, Fourman MS, Phillips BT, et al. Modeling fade patterns of nipple areola complex tattoos following breast reconstruction. Ann Plast Surg 2014; 73(Suppl. 2): S153-6. [http://dx.doi.org/10.1097/SAP.0000000000000120] [PMID: 24727445]

[48] Tomita S, Mori K, Miyawaki T. Color change after paramedical pigmentation of the nipple-areola complex. Aesthetic Plast Surg 2018; 42(3): 656-61. [http://dx.doi.org/10.1007/s00266-017-1057-y] [PMID: 29302729]

[49] Vadodaria SJ, Vadodaria BS. Tattooing for the management of white patches. Ann Plast Surg 1989; 23(1): 81-3. [http://dx.doi.org/10.1097/00000637-198907000-00013] [PMID: 2764464] 
[50] Lea PJ, Pawlowski A. Human tattoo. Electron microscopic assessment of epidermis, epidermal-dermal junction, and dermis. Int J Dermatol 1987; 26(7): 453-8. [http://dx.doi.org/10.1111/j.1365-4362.1987.tb00590.x] [PMID: 3654039]

[51] Hallock GG. Salvage by tattooing of areolar complications following breast reduction. Plast Reconstr Surg 1993; 91(5): 942-5. [http://dx.doi.org/10.1097/00006534-199304001-00035] [PMID: 8460199]

[52] Garg G, Thami GP. Micropigmentation: Tattooing for medical purposes. Dermatol Surg 2005; 31(8 Pt 1): $928-31$. [http://dx.doi.org/10.1097/00042728-200508000-00007] [PMID: 16042938]

[53] Goh SC, Martin NA, Pandya AN, Cutress RI. Patient satisfaction following nipple-areolar complex reconstruction and tattooing. J Plast Reconstr Aesthet Surg 2011; 64(3): 360-3. [http://dx.doi.org/10.1016/j.bjps.2010.05.010] [PMID: 20570584]

[54] Halvorson EG, Cormican M, West ME, Myers V. Three-dimensional nipple-areola tattooing: A new technique with superior results. Plast Reconstr Surg 2014; 133(5): 1073-5. [http://dx.doi.org/10.1097/PRS.0000000000000144] [PMID: 24776543]

[55] Chang SE, Kim KJ, Choi JH, Sung KJ, Moon KC, Koh JK. Areolar cosmetic tattoo ink darkening: A complication of Q-switched alexandrite laser treatment. Dermatol Surg 2002; 28(1): 95-6. [PMID: 11991280]

[56] Chang BW, Slezak S, Goldberg NH. Technical modifications for on-site nipple-areola reconstruction. Ann Plast Surg 1992; 28(3): 277-80. [http://dx.doi.org/10.1097/00000637-199203000-00014] [PMID: 1575430]

[57] Adams WM. Labial transplant for correction of loss of the nipple. Plast Reconstr Surg (1946) 1949; 4(3): $295-8$. [http://dx.doi.org/10.1097/00006534-194905000-00009] [PMID: 18131359]

[58] Edwards EA, Duntley SQ. The pigments and color of human skin. Am J Anat 1939; 65: 1-33. [http://dx.doi.org/10.1002/aja.1000650102]

[59] Broadbent TR, Woolf RM, Metz PS. Restoring the mammary areola by a skin graft from the upper inner thigh. Br J Plast Surg 1977; 30(3): 220-2.

[http://dx.doi.org/10.1016/S0007-1226(77)90094-7] [PMID: 329932]

[60] Schwartz AW. Reconstruction of the nipple and areola. Br J Plast Surg 1976; 29(3): 230-3. [http://dx.doi.org/10.1016/S0007-1226(76)90062-X] [PMID: 779905]

[61] Farhadi J, Maksvytyte GK, Schaefer DJ, Pierer G, Scheufler O. Reconstruction of the nipple-areola complex: An update. J Plast Reconstr Aesthet Surg 2006; 59(1): 40-53.

[http://dx.doi.org/10.1016/j.bjps.2005.08.006] [PMID: 16482789]

[62] Brent B, Bostwick J. Nipple-areola reconstruction with auricular tissues. Plast Reconstr Surg 1977; 60(3): 353-61. [PMID: 331365]

[63] Broadbent TR, Woolf RM, Metz PS. Restoring the mammary areola by a skin graft from the upper inner thigh. Br J Plast Surg 1977; 30(3): 220-2.

[http://dx.doi.org/10.1016/S0007-1226(77)90094-7] [PMID: 329932]

[64] Becker H. The use of intradermal tattoo to enhance the final result of nipple-areola reconstruction. Plast Reconstr Surg 1986; 77(4): 673-6. [http://dx.doi.org/10.1097/00006534-198604000-00032] [PMID: 3952225]

(C) 2018 Simonacci et al.

This is an open access article distributed under the terms of the Creative Commons Attribution 4.0 International Public License (CC-BY 4.0), a copy of which is available at: https://creativecommons.org/licenses/by/4.0/legalcode. This license permits unrestricted use, distribution, and reproduction in any medium, provided the original author and source are credited. 